\title{
Financial Performances and Public Procurement Loss: Indonesia Ministries/State Study
}

\author{
Rosinta H. F. Purba ${ }^{a, *}$, \& Amirullah S. Hardi ${ }^{a}$ \\ ${ }^{a}$ Faculty of Economics and Business, Universitas Gadjah Mada, Indonesia
}

\begin{abstract}
Transparency of public acquisition is one of the core mechanisms in combating corruption. However, in Indonesia, despite the transparency of audit results of the Ministry/State Agency's financial statement related to Unqualified Opinions published by the State Audit Agency has increased yearly, the trends of corruption cases increased as well. This research aims to investigate the determinants of financial performances and the state financial loss using panel data of 74 Indonesia ministries/state agencies between 2014-2016, further employing the random effects analysis to overcome serial correlation. The main findings indicate that unqualified opinion positively and significantly reduces the state financial loss in Indonesia. Besides, political party leadership (non-independent Minister) significantly influenced the state financial loss. Furthermore, capital expenditure and state expenditure allocation significantly influenced the state financial loss in Indonesia while accountability score was not important determinants of financial loss in Indonesia.
\end{abstract}

Keywords: public procurement; loss; unqualified opinion; political party; ministry JEL Classification: H57

${ }^{*}$ Corresponding Author: Jln. Nusantara, Bulaksumur, Yogyakarta, Indonesia 55281. E-mail: rosinta. h.f@mail.ugm.ac.id. 


\section{Introduction}

Of late in Indonesia, the Anti-Corruption Clearing House (ACCH) of Corruption Eradication Commission data signals 648 cases of criminal act of corruption in September 2017. Of which many of the cases were generally in forms of goods / service provision, permission, impediment of performances of Corruption Eradication Commission, budget misuse, bribe, and criminal act of money laundering. More to the point, the weak legal maintenances and high bribery offerings and requests to justice leagues of Indonesia become two of the main arguments increasing the trend of criminal acts of corruption cases.

In 2001, the Indonesian Corruption Watch (ICW) surveyed six regions in Indonesia and argued that there was an increasing trend of criminal act of corruption cases because of frequent case brokers (judicature mafias) performed by parties besides legal enforcing apparatuses that previously promised to be an inter-mediating party between the justice seekers (demand) and legal enforcement apparatuses (supply). A case study reported that bribery cases conducted to the Indonesian judicature agencies occurred in all court levels, either directly or indirectly, by hiring an inter-mediating party (Safyra, 2017). More so, the criminal act of corruption was mostly contributed by ministries/state agencies of the Republic of Indonesia by 262 of 648 cases. Furthermore, the criminal act was also frequently contributed by the local government in 148 cases. This situation is reflected by administrative indicators in all states. In 2011, Indonesian was ranked the 100th of 183 states, assessed by the Corruption Perceptions Index 2017.

Public transparency is the key factor to eradicate corruption (Kenny, 2012). Notes of investigation on financial statements of ministries/state agencies written by the Corruption Eradication Commission as an external audit can represent to what extent the audited ministries/state agencies have met a good qualification of administrative achievement including eradication act against corruption (State Audit Agency of the Republic of Indonesia [BPK RI], 2016). However, the transparency of audit results of Financial Statements of Ministries/State Agencies held by the State Audit Agency is unable to represent the cases of corruption in Indonesia. The occurring phenomenon is the acquisition of Financial Statements of Ministries/State Agencies related to unqualified opinions published by the State Audit Agency increases yearly. In 2010-2014, the percentage of unqualified opinion acquisition was the biggest portion achieved by ministries/state agencies from 2010 to 2014, the percentage of unqualified opinion had the biggest portion in ministries/state agencies if compared to the qualified, unfair, and disclaimer opinion. In 2010, there were 50 ministries/state agencies obtaining unqualified opinion, i.e. $64.93 \%$ of 77 ministries/state agencies audited by the State Audit Agency, followed by qualified opinion of $32.47 \%$; while the smallest portion was disclaimer opinions with $2.60 \%$. However, no ministries/state agencies were obtaining unfair opinions from 2010 until 2014.

This case indicates a serious gap in the rationalization of good management 
measurement (the State Audit Agency opinion) in investigating the financial reports including the detection of budget manipulation, toward the reality of corrupt behavior done by the public officer in it. Moreover, the allegation that the State Audit Agency opinion can be traded is not only entangling the local government but also the officer of ministries/state agencies. According to ICW, during 2005-2017, has recorded that there are 6 bribe cases involving 23 auditors/officers/Staff of the State Audit Agency. There are three bribe cases to obtain the unqualified opinion, one bribe case to obtain a modified opinion, one bribe case to change the findings of the State Audit Agency, and one bribe case to "smoothen" the audit process of the State Audit Agency. Based on the data of finding on country financial loss, i.e. disobedience toward the stipulations of legislation on inspection result in 2014-2016, it has been revealed that there are 1426 findings worth IDR1,016.72 trillion.

\section{Literature Review}

Several kinds of studies have been done related to the identification of the causes of corruption in some countries. Most of the researches use some economic variables such as salary degree (Tanzi, 1998), economic growth (Ata \& Arvas, 2011; Paldam, 2002), economic freedom (Paldam, 2002), the variability of inflation (Braun \& Di Tella, 2004), regulation (Treisman, 2000) and tax (Silaen \& Sasana, 2013). The previous researches use the data of Corruption Perception Index as a proxy to assess the corruption level, however, it is limited on the unit of analysis in the region of Province only while the assessment for ministries/state agencies is still very limited. Nevertheless, the shortcoming of data becomes the opportunity for the author to give the contribution toward the literature.

The investigation research related to budget misappropriation in ministry/state agency financial statement used the data of country financial loss in the report of ministry/state agency financial statement inspection result by the State Audit Agency of the Republic of Indonesia, to find out the influence of ministry/state agency financial performance assessment, i.e. the opinion of State Audit Agency on the country finance. Furthermore, to answer how the dependent variables such as accountability score, the total expense of the country, the total expense of capital, Indonesian Democracy Index (IDI) score, and ministry/state agency leadership by the politician of party influence the country financial loss. The urgency of this study endeavor to pointed out the incompatibility of financial performance measurements and the trend of increased procurement loss cases.

\section{Method}

Data used was panel data from 74 Ministries/State Agencies from 2014 to 2016. Data used in this research included data on financial loss from Audit Reports of the State Audit Agency of the Republic of Indonesia, the opinion of financial statement audit, accountability score report by Ministry of Administrative and 
Bureaucratic Reform of Republic of Indonesia, total state expenditure of each ministry/state agency, total capital expenditure allocation of each ministry/state agency, a dummy of ministry/state agency leadership by party politician, and Indonesian Democracy Index by the National Social Security as shown in Table 1. The main problem of panel data utilization if estimated by employing OLS was the serial correlation problem, error $\left(a_{i}\right)$, correlated inter-period. If the unobserved heterogeneity $a_{i}$ were ignored, estimation would be biased. The method to solve such a problem was differencing. To eliminate $a_{i}$, differencing is useful to eliminate causal effects. FD estimation seemed promising and could create an efficient estimator, but only accommodated panel data in a certain period $\mathrm{T}$ (year) $=2$. If $\mathrm{T}>2$, the problem probability of serial correlation (heteroskedasticity) would increase, making estimation unbiased but making estimators inefficient (Wooldridge, 2013). Moreover, the observation year of this research was 20142016, so FD could not be hired as an estimation method.

RE estimation was called the Error Component Model (ECM). It was assumed when $a_{i}$ could not be correlated to the explanatory variable, $\operatorname{Cov}\left(X_{i t j}, a_{i}\right)=0, a_{i}$ had to be independent of $X_{i}$. Inter-period composite errors $v_{i t}$ i made positive serial correlation cause incorrect estimation of error standard. Meanwhile, estimation using RE had to fulfill three assumptions that were: (i) there was no perfect linear relationship among explanatory variables; (ii) $E\left(a_{i} \mid X_{i}\right)=\beta_{0}$, there was no correlation between $a_{i}$ and explanatory variables. $a_{i}$ was inter-period constant; and (iii) $\operatorname{Var}\left(a_{i} \mid X_{i}\right)=\sigma_{u}^{2}$, the variant was constant and there was no inter-period correlation.

As $a_{i}$ is correlated across periods, the Generalized Least Square (GLS) technique could be implemented to solve serial correlation problems.

$$
y_{i t}-\theta \bar{y}_{\iota}=\beta_{0}(1-\theta)+\beta_{1}\left(X_{i t 1}-\theta \bar{X}_{i 1}\right)+\beta_{k}\left(X_{i t k}-\theta \bar{X}_{i k}+\left(v_{i t}-\theta \bar{v}_{i}\right)\right.
$$

Gujarati and Porter (2009) argued that the estimation model utilizing the Generalized Least Square (GLS) method met classical assumptions. However, this research presents the results of heteroskedasticity and normality tests. Hausman test would not be necessary to be the the base of model selection between FE and RE because unable to accommodate when shock correlated inter-period (serial correlation), making Hausman test invalid (Wooldridge, 2002). Its utilization was based on the relation between and chosen based on previous assumptions and research. When the sample could not be treated as random (as data of provinces, regencies, etc.), FE should have been used since more accurate to analyze aggregate data than RE. However, when the research time series was smaller than the total analysis unit (cross-section), RE should have been used (Baltagi, 2005). The research model referred to the model generally applied for panel data by modifying the research model of Nurhasanah (2016).

$$
L K e r_{i t}=\beta_{0}+\beta_{1} O p_{i t}+\beta_{2} \Gamma X_{i t}+v_{i t}
$$


where:

$\operatorname{LKer}_{i t}$ : the level of state financial loss of $K / L_{i}$ in the period $t$;

$O p_{i t}$ : the opinion of State Audit Agency on an audit of $L K K L_{i}$ in the period $t$;

$\Gamma X_{i t}$ : the variable vector of accountability score of $L K K L_{i}$ in the period $t$, Ln state expenditure of $L K K L_{i}$ in the period $t$, Ln capital expenditure of $L K K L_{i}$ in the period $t$, and control variables that were dummy of party politician leadership of $L K K L_{i}$ in the period $t$;

$\beta$ : constanta;

$\beta_{1}-\beta_{2}$ : regression coefficient;

$u_{i t}:$ Idiosyncratic error.

\section{Result}

\subsection{Heterokesdacity test}

In general, heteroskedasticity did make indicators biased, but generated errors particularly in the measurement of standard error, degenerating efficiency (the OLS method estimator did not have any minimum variance anymore). Breusch Pagan test implied Prob>chi-square was more than 0.05 , so $\mathrm{H}_{0}$ was not rejected, indicating that the RE model did not have any heteroskedasticity issues.

\subsection{Normality test}

The normality test aimed to investigate if, in the regression model, errors were normally distributed. The regression model could be assessed as good if having a normal data distribution or close to normal data distribution. The test was performed by conducting a histogram graphic analysis and Swilk error test.

Based on results presented normally distributed data were observed from the result of the Shapiro-Wilk test, whether it was significant at 0.05867 or more than 0.05 . This proved that residual data were normally distributed. On the other words, the data could be employed in further tests.

\subsection{Estimation results of model}

The results of the regression analysis shown in Table 1 implied that p-value (Prob $>$ F) was $0.0000<0.05$ (significance level), so $H_{0}$ was rejected and $H_{a}$ was accepted. Therefore, all explanatory and control variables simultaneously influenced on dependent variables.

$$
\begin{aligned}
\text { Ln_loss }_{i t}= & 10.809+0.963 \text { opinion_State Audit Agency }_{i t}+0.283 \text { accountability }_{i t} \\
& +0.303 \text { l Ln_expenditure } \\
& +0.447 \text { Ln_capital }_{i t}+0.697 \text { politician }_{i t}+e_{i t}
\end{aligned}
$$

In Table 1, the opinion of State Audit Agency (opinion'State Audit Agency) positively and significantly influenced the financial state loss (ln_loss) at the 
Financial Performances and Public Procurement Loss ...

significance level of $1 \%$. The results signals that in instance the changes of State Audit Agency opinion increased by 1 (opinion: 1-4, high to low), indicating deteriorated opinion quality, then the state financial loss would increase by $0.962 \%$ in Indonesia, ceteris paribus. Perhaps a possible justification is that of late in Indonesia in Indonesia recently made a war effort against corruption through an independent institution, the Corruption Eradication Commission. Also, the Government has intensified the role of institutions and empowered institutions in terms of transparency and accessibility of data through bureaucratic cuts.

The variable of state expenditure (lexpenditure) and capital expenditure (lcapital) positively and significantly influenced the state financial loss (llos) by 0.303 and 0.447 at the significance level of $10 \%$ and $5 \%$, respectively.

Table 1: Estimation Results of Robustness Random Effect GLS Regression with Comparison

\begin{tabular}{llllll}
\hline \multicolumn{7}{c}{ Dependent variable: Financial loss (Ln_Loss) } \\
\hline Independent Variables & OLS & $\begin{array}{l}\text { Random } \\
\text { Effect (RE) }\end{array}$ & $\begin{array}{l}\text { Robustness } \\
\text { cluster RE }\end{array}$ & $\begin{array}{l}\text { Fixed } \\
\text { Effect (FE) }\end{array}$ & $\begin{array}{l}\text { Robustness } \\
\text { Cluster } \\
\text { (FE) }\end{array}$ \\
\hline Opinion State Audit & $.999988^{* * *}$ & $0.963202^{* * *}$ & $0.963202^{* * *}$ & $0.9217642^{* * *}$ & $0.9217542^{* * *}$ \\
Agency & & & & \\
& $(.157)$ & $(.156)$ & $(.154)$ & $(.193)$ & $(.192)$ \\
Accountability & 0.0320771 & $0.0283189^{*}$ & 0.0283189 & 0.0662522 & 0.0662522 \\
& $(.019)$ & $(0.023)$ & $(0.027)$ & $(0.065)$ & $(0.072)$ \\
Ln_expenditure & $.435058^{* * *}$ & $.3030427^{*}$ & $.3030427^{*}$ & -0.3108842 & -0.3108842 \\
& $(.139)$ & $(.160)$ & $(.170)$ & $(.345)$ & $(.212)$ \\
Ln_capital & $.350788^{* * *}$ & $.4471917^{* * *}$ & $.4471917^{* *}$ & $.7791356^{* * *}$ & $.7791356^{* * *}$ \\
& $(.113)$ & $(.126)$ & $(.142)$ & $(.217)$ & $(.276)$ \\
politician & $.5961016^{*}$ & $.6967701^{*}$ & $.6967701^{* *}$ & 0.5498039 & 0.5498039 \\
& $(.326)$ & $(.361)$ & $(.340)$ & $(.576)$ & $(.593)$ \\
_cons & 10.10385 & 10.80963 & 10.80963 & 13.76288 & 13.76288 \\
& $(8.154)$ & $(7.338)$ & $(8.637)$ & $(13.671)$ & $(12.578)$ \\
\hline N & 211 & 211 & 211 & 211 & 211 \\
R-squared & 0.4835 & 0.2118 & 0.2118 & 0.2371 & 0.2371 \\
Mean VIF & 1.88 & - & - & - & - \\
\hline
\end{tabular}

Source: Authors compution Using STA 14

Notes: (i) standard errors in parentheses, (ii) ${ }^{*} ;{ }^{* *} ;{ }^{* *}$ significant level $10 \% ; 5 \% ; 1 \%$ repectively

If the percentage of changed capital expenditure increased by $1 \%$, the state financial loss increased by $0.303 \%$, cateris paribus. Furthermore, if the percentage increased by $1 \%$, the state financial loss increased by $0.447 \%$, cateris paribus. It was in line with the research done by Jajkowicz and Drobiszová (2015) in 21 OECD countries in 1998-2011 implying that the government expenditure for public defenses and services showed that increased government expenditure for such necessities increases the corruption occurrence.

Amundsen (2006) research conveyed that strong leaders would have strong controls on corruption and could decide which party earning the largest benefit after conducting corruption was. It confirmed the fact that the variable of party politician leadership (politician) positively and significantly the state financial 
loss (lloss) by 0.697 with the significance level of $5 \%$. Nevertheless, accountability scores (accountability) insignificantly affected the state financial loss (lloss).

\section{Conclusions}

The opinion of State Audit Agency is a good administrative standard. Increased quality of ministry/state agency financial statement evidenced by increased opinions of State Audit Agency was proportional to decreased state financial loss at the significance level of 1\%, implying that opinion of State Audit Agency is potential to be an effective tool in the corruption eradication act conducted to ministries/state agencies. Furthermore, the improvement of internal systems and resources to overcome bribery during the gaining process of State Audit Agency opinion because of the Financial Statement of Ministry/State Agency.

Fragile goods and services provision attempts cause state financial loss. Restriction of state financial allocation, design supervision, and capital expenditure allocation is important needs to be performed at ministries/state agencies with a large percentage of state financial loss. Therefore, this research can be one of the fundamental considerations in designing the expenditure budget of ministries/state agencies.

Ministries/state agencies led by a representative of certain political parties increased the prevalence of state financial loss in the significance level of $5 \%$, hence if a ministry/state agency was led by a politician belonging to a political party, then the financial state loss would increase. This entailed to these following ideas: first, election of ministry or agency heads were based on the candidates' professionalism, not on which party they belonged to that make them prioritize their parties' importance and second, restructuration of party cadre formation system by avoiding transactional systems has commonly happened since cadre recruitment.

State Audit Agency should improve low-quality recommendations processed by ministries / state agencies. This is intended to strictly overcome recommendations given by the State Audit Agency experiencing mounted recommendations as those recommendations had not been or were not processed by ministries/state agencies. The State Audit Agency should cooperate with the Corruption Eradication Commission in dealing with unprocessed recommendations.

However, this research has limitations, particularly on its operational variables due to multidimensional corruption. KPMG of Fraud, Bribery, and Corruption Survey 2013 proposed that corruption occurring in Australia and New Zealand in 2012 was caused by a weak internal control by $28 \%$ of respondents that there was an abandonment of existing internal controlling system by $19 \%$. Moreover, $42 \%$ of fraud was mostly caused by internal control (KPMG, 2013). Therefore, the utilization of institutional internal controlling system score variables should be considered by future researchers. 


\section{Acknowledgment}

I would like to thank Prof. Juraj Nemec, David Mendy, and anonymous reviewers.

\section{References}

[1] Amundsen, I. (2006). Political corruption. U4 Issue 2006:6. Bergen: Chr. Michelsen Institute. http://hdl.handle.net/11250/2474792.

[2] Ata, A. Y., \& Arvas, M. A. (2011). Determinants of economic corruption: a crosscountry data analysis. International Journal of Business and Social Science, 2(13), 161-169.

[3] Baltagi, B. H. (2005). Econometrics analysis of data panel (3rd edition) Chichester: John Wiley \& Sons Ltd. [

[4] BPK RI [State Audit Agency of the Republic of Indonesia]. (2016). Rencana strategis 2016-2020. https://www.bpk.go.id/assets/files/storage/2016/05/file_storage_ 1462187801.pdf.

[5] Braun, M., \& Di Tella, R. (2004). Inflation, inflation variability, and corruption. Economics \& Politics, 16(1), 77-100. doi: https://doi.org/10.1111/j.14680343.2004.00132.x.

[6] Gujarati, D. N. \& Porter, D. C. (2009). Basic econometrics (5th Edition). McGraw Hill Inc., New York.

[7] Jajkowicz, O., \& Drobiszová, A. (2015). The effect of corruption on government expenditure allocation in OECD countries. Acta Universitatis Agriculturae et Silviculturae Mendelianae Brunensis, 63(4), 1251-1259. doi: http:/ /dx.doi.org/10.11118/actaun201563041251.

[8] Kenny, C. (2012, May). Publishing construction contracts to improve efficiency and governance. In Proceedings of the Institution of Civil EngineersCivil Engineering (Vol. 165, No. 5, pp. 18-22). Thomas Telford Ltd. doi: https://doi.org/10.1680/cien.11.00007.

[9] KPMG. (2013). The KPMG survey of corporate responsibility reporting 2013. https://home.kpmg/ru/en/home/insights/2013/12/ the-kpmg-survey-of-corporate-responsibility-reporting-2013.html.

[10] Nurhasanah. (2016). Efektivitas pengendalian internal, audit internal, karakteristik instansi dan kasus korupsi (studi empiris di kementerian/lembaga). Jurnal Tata Kelola \& Akuntabilitas Keuangan Negara, 2(1), 27-48. doi: http://dx.doi.org/10.28986/jtaken.v2i1.35.

[11] Paldam, M. (2002). The cross-country pattern of corruption: economics, culture and the seesaw dynamics. European Journal of Political Economy, 18(2), 215-240. doi: https:/ /doi.org/10.1016/S0176-2680(02)00078-2.

[12] Safyra, N. (2017). Pemodelan suap peradilan di indonesia dengan pendekatan game theory (Undergraduate thesis, Universitas Gadjah Mada).

[13] Silaen, F. Y., \& Sasana, H. (2013). Analisis determinan korupsi di era otonomi daerah di Indonesia (Studi kasus Provinsi Jawa Tengah). Diponegoro Journal of Economics, 2(1), 227-232.

[14] Tanzi, V. (1998). Corruption around the world: causes, consequences, scope, and cures. IMF Working Paper WP/98/63. International Monetary Fund. https://www.imf.org/en/Publications/WP/Issues/2016/12/30/ Corruption-Around-the-World-Causes-Consequences-Scope-and-Cures-2583. 
[15] Treisman, D. (2000). The causes of corruption: a cross-national study. Journal of Public Economics, 76(3), 399-457. doi: https:/ /doi.org/10.1016/S0047-2727(99)00092-4.

[16] Wooldridge, J. M. (2002). Econometric analysis of cross section and panel data. MIT Press.

[17] Wooldridge. J. M. (2013). Introductory econometrics: A modern approach (5th edition). USA: South-Western Cencage Learning. 
this page intentionally left blank 